\title{
KONSTRUKSI MAKNA NASIONALISME PADA DESAIN UANG RUPIAH KERTAS
}

\author{
Lingga Yonita, Hanny Hafiar, Anwar Sani \\ Fakultas Ilmu Komunikasi, Universitas Padjadjaran Bandung. \\ ega.linggayonita@gmail.com, hannyhafiar@gmail.com,nasirawon@gmail.com \\ Diajukan: 20-12-2017; Direview: 15-01-2018; Diterima: 26-05-2018
}

\begin{abstract}
This research is based on the controversial expenditure of 2016's rupiah banknotes. Theory used in this research is Charles Sanders Peirce's semiotics theory. This research aims to figure out the symbols contained in 2016's banknotes emission of rupiah, the meanings of those symbols, and how those symbols can construct the value of nationalism. The result of this research shows that symbols contained in the 2016's rupiah banknotes are garuda pancasila, text "Negara Kesatuan Republik Indonesia", text "Bank Indonesia", text "Seribu, Dua Ribu...Seratus Ribu Rupiah", Minister of Finance's and Bank Indonesia's governor's signs, text "Dengan rahmat Tuhan...", national hero, local dances, natural attractions, flowers, and batik. The conclusion of this research is there are eleven main symbols contained in the 2016's banknotes designs of rupiah. The meanings of those symbols are able to construct the meaning of Autonomous, Unity, and Identity which an element of nationalism.
\end{abstract}

Keywords: Symbols, Semiotics, Charles Sanders Peirce, Banknotes of Rupiah, Nationalism.

\begin{abstract}
Abstrak
Penelitian ini dilatarbelakangi oleh kontroversi pengeluaran uang Rupiah kertas tahun emisi 2016. Dengan menggunakan teori semiotika Charles Sanders Peirce, penelitian ini bertujuan untuk mengetahui simbol yang terdapat dalam uang Rupiah kertas TE 2016, makna yang terkandung di dalam simbol tersebut, dan bagaimana simbol-simbol tersebut dapat mengkonstruksi makna nasionalisme. Hasil penelitian menunjukkan simbol yang hadir dalam uang Rupiah kertas TE 2016 ialah simbol garuda pancasila, simbol teks Negara Kesatuan Republik Indonesia dan gambar peta Indonesia, simbol teks "Bank Indonesia", simbol teks "Seribu, Dua Ribu...Seratus Ribu Rupiah", simbol tanda tangan Menteri Keuangan dan Gubernur Bank Indonesia, simbol teks "Dengan Rahmat Tuhan...", simbol pahlawan nasional, simbol tarian daerah, simbol tempat wisata alam, simbol bunga, dan simbol motif batik. Kesimpulan dari penelitian ini ialah terdapat sebelas simbol utama dalam desain uang Rupiah kertas TE 2016. Kesebelas simbol tersebut memiliki makna yang mampu mengkonstruksi makna Autonomous, Unity, dan Identity yang menjadi unsur dalam nasionalisme.
\end{abstract}

Kata Kunci: Simbol, Semiotika, Charles Sanders Peirce, Uang Rupiah Kertas, Nasionalisme.

\section{PENDAHULUAN}

$\mathrm{P}$ ada 19 Desember 2016 Bank Indonesia mengeluarkan uang Rupiah kertas dengan desain terbarunya. Beberapa pecahan uang Rupiah kertas yang baru diluncurkan ialah $\mathrm{Rp}$ 100.000,- Rp 50.000,- Rp 20.000,- Rp 10.000,- Rp $5.000,-$ Rp 2.000,- dan Rp 1.000. Secara visual memang nampak perbedaan gambar uang Rupiah kertas baru dengan yang sebelumnya. Perbedaan tersebut nampak pada berbagai gambar yang hadir dalam desain uang Rupiah kertas pada pengeluaran uang Rupiah tahun 2016 atau yang disebut Tahun Emisi 2016. Menurut Bank Indonesia penggunaan gambar-gambar dalam uang Rupiah kertas Tahun Emisi 2016 diharapkan dapat membangkitkan rasa cinta tanah air masyarakat Indonesia (www.bi.go. 
id). Namun uang Rupiah kertas yang diharapkan mampu meningkatkan rasa nasionalisme justru diterpa berbagai isu negatif terkait desainnya. Beberapa masyarakat Indonesia menganggap bahwa desain uang Rupiah kertas yang baru mirip dengan mata uang negara China (detik.com).

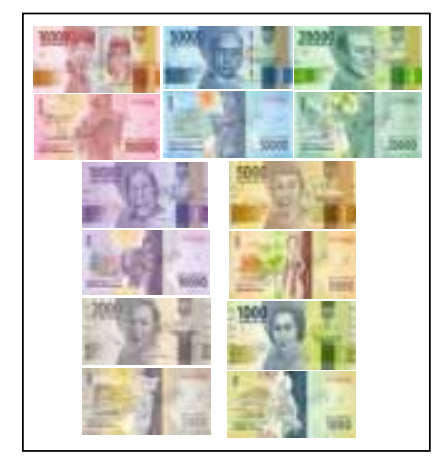

Gambar 1.

Desain Uang Rupiah Kertas Tahun Emisi 2016

Bukan hanya itu, desain uang kertas baru juga dianggap memuat simbol PKI. Hal ini yang kemudian semakin menguatkan berbagai isu negatif mengenai simbol-simbol yang hadir dalam uang Rupiah kertas. Kontroversi mengenai desain uang kertas baru tersebut memberikan indikasi bahwa Rupiah seolah-olah tidak mengandung unsur nasionalisme. Padahal, mata uang menjadi media yang mampu mengkonstruksi nasionalisme.

Menurut Eric Helleiner, "mata uang dalam sebuah territorial mampu membangun kesepahaman, kesatuan, dan nasionalisme melalui penyampaian simbolsimbol kedaulatan negara di dalam mata uang tersebut. Hal inilah yang kemudian menjadikan mata uang sebagai media yang paling efektif dibandingkan bendera dan lagu kebangsaan untuk menyampaikan pesanpesan nasionalisme" (Helleiner, 2005).

Hadirnya berbagai isu negatif mengenai uang Rupiah kertas tersebut menjelaskan bahwa terdapat perbedaan makna yang ditangkap oleh pembuat desain dan pengguna uang Rupiah. Oleh karenanya, penelitian ini berusaha untuk menjembatani gap permasalahan tersebut dengan sebuah penelitian semiotika. Mengacu pada penjelasan artikel berikut, Analisis semiotika disebut sebagai ilmu yang mengkaji tanda dalam kehidupan manusia. Artinya, semua yang hadir dalam kehidupan kita dapat dilihat sebagai tanda, yakni sesuatu yang harus kita beri makna (Victor, 2016). Semiotika juga dapat digunakan untuk melihat bagaimana simbol dapat mengonstruksi sesuatu (Hafiar, Mahameruaji, \&Rahmawan, 2017).

\section{LITERATUR DAN METODOLOGI Literatur}

Uang kertas yang hadir sebagai alat tukar memang bukan hanya memiliki fungsi ekonomi bagi sebuah negara namun juga memiliki fungsi komunikasi yang menyampaikan pesan melalui berbagai simbol yang dihadirkannya. Kehadiran uang kertas yang digunakan oleh masyarakat menjadikannya memiliki fungsi sebagai media komunikasi massa yang di desain secara khusus dan digunakan oleh masyarakat luas dalam setiap harinya.

"According to Hewitt currency is 'among the most mass-produced objects in the world, painstakingly designed for millions of people to use' and as such 'a banknote is in effect an advertisement,' offering 'an unparalleled opportunity for officially-sanctioned propaganda', to colour the recipients view" (Andrew, 2014).

Berdasarkan fungsinya tersebut kemudian uang kertas mampu menjadi media yang menyampaikan pesan nasionalisme bagi masyarakat dalam sebuah negara. Pesan ini hadir dalam simbol-simbol yang ditampilkan dalam uang Rupiah kertas seperti simbol mengenai sejarah nasional, kekayaan alam hingga politik negara. "As a medium of mass communication, then, national currency represent a powerful assertion of state power and nationalism" (Lauer, 2008).

\section{Metodologi Penelitian}

Metode penelitian yang digunakan peneliti ialah metode penelitian kualitatif. Bogdan dan Taylor mendefinisikan metodologi kualitatif sebagai prosedur penelitian yang menghasilkan data deskriptif berupa kata-kata tertulis atau lisan dari orang-orang dan perilaku yang dapat diamati 
(Moleong, 2012: 4)

\section{Teknik Analisis Data}

Semiotika yang digunakan dalam penelitian ini ialah semiotika Peirce yang dikenal dengan model triadic dan konsep trikotominya. Konsep trikotomi membahas mengenai tiga kategori tanda yakni firstness, secondness, dan thirdness. Dalam hal ini Bank Indonesia selaku pembuat desain uang Rupiah merupakan komunikator atau firstness yang memiliki pemahaman mengenai makna nasionalisme yang disampaikan melalui desain uang Rupiah kertas. Sementara itu, masyarakat Indonesia sebagai pengguna uang Rupiah kertas merupakan kategori thirdness yang juga memiliki pemahaman tersendiri terkait makna yang hadir dalam simbol-simbol uang Rupiah kertas. Dengan begitu, sebagai usaha untuk menjembatani antara pembuat desain dengan pengguna uang Rupiah kertas, terkait makna yang hadir pada simbol uang Rupiah kertas TE 2016 peneliti menggunakan konsep trikotomi tanda dalam semiotika peirce.

Trikotomi pertama dalam sistem tanda Peirce ialah representamen. Sign (Representamen) merupakan bentuk fisik atau segala sesuatu yang dapat diserap pancaindra dan mengacu pada sesuatu (Vera, 2014: 24). Dari sudut pandang representamen, Peirce membagi tanda-tanda menjadi qualisign, sinsign, dan legisign (Nöth, 1995:44). Trikotomi kedua pada sistem tanda Peirce adalah objek. Objek dapat berupa representasi mental (ada dalam pikiran), dapat juga berupa sesuatu yang nyata di luar tanda (Vera, 2014: 21).Pada trikotomi keduatanda-tanda diklasifikasikan oleh Peirce menjadi ikon (icon), indeks (index), dan simbol (symbol) (Budiman, 2011: 78). Trikotomi ketiga dalam semiotika Peirce ialah interpretan. Interpretan merupakan proses mengadaptasi makna dari tanda dengan pengalaman pribadi dan sosial (Danesi, 2011 :38). Dalam trikotomi ini tanda dibagi menjadi rheme, dicent, dan argument.

Dalam penelitian ini, peneliti menggunakan kesembilan tipe tanda pada trikotomi semotika Charles S. Peirce dalam menganalisis masingmasing simbolnya. Kata "simbol" yang digunakan peneliti ialah simbol yang terdapat dalam konsep semiotika Peirce. Peirce mendefinisikan simbol sebagai suatu tanda dimana hubungan tanda dan denotasinya ditentukan oleh suatu kesepakatan bersama (konvensi). Simbol tersebut baru dapat dipahami jika seseorang sudah mengerti arti yang telah disepakati sebelumnya (Vera, 2014: 24-25).

Tabel 1. Trikotomi Semiotika Peirce

\begin{tabular}{|l|c|c|c|}
\hline Kategori & Representamen & Objek & Interpretan \\
\hline Otonstness & Qualisign & Ikon & Rheme \\
\hline $\begin{array}{l}\text { Secondness } \\
\text { Disambugkan } \\
\text { dengan realitas }\end{array}$ & Sinsign & Indeks & Dicent \\
\hline $\begin{array}{l}\text { Thirdness } \\
\begin{array}{l}\text { Dihubungan } \\
\text { dengan aturan, } \\
\text { konvensi, atau } \\
\text { kode }\end{array}\end{array}$ & Legisign & Simbol & Argument \\
\hline
\end{tabular}

Sumber: Noth, 1995:45

\section{Teknik Pengumpulan Data}

Teknik pengumpulan data yang digunakan pada penelitan ini dalah observasi, wawancara, dan studi pustaka. Jenis observasi non partisipan dipilih oleh peneliti untuk melihat bagaimana masyarakat Indonesia melihat berbagai simbol yang hadir dalam desain uang Rupiah kertas tahun emisi 2016. Sementara itu, wawancara dilakukan peneliti untuk mengkonfirmasi data dan interpretasi. Konfirmasi dilakukan pada Harifa Ali Albar, Dosen FSRD ITB sebagai triangulator. Studi pustaka dilakukan peneliti dengan pencarian data dan informasi terhadap literatur yang relevan dengan topik penelitian, baik dokumen tertulis, foto-foto, gambar, maupun dokumen elektronik yang dapat mendukung proses penulisan.

\section{Teknik Validitas Data}

Teknik validitas data dalam penelitian ini menggunakan triangulasi sumber. Patton mendefinisikan triangulasi sumber berarti membandingkan dan mengecek balik derajat kepercayaan suatu informasi yang diperoleh melalui waktu dan alat yang berbeda dalam metode kualitatif (Moleong, 2012: 330). 


\section{TEMUAN DAN DISKUSI}

Berdasarkan hasil penelitian, pada uang Rupiah kertas TE 2016 terdapat 11 simbol yang mengkonstruksi makna nasionalisme. Sebelas simbol tersebut kemudian diklasifikasikan menjadi dua bagian yaitu simbol yang seragam pada setiap pecahan uang Rupiah kertas dan simbol yang berbeda pada masing-masing pecahan.

\begin{tabular}{|c|c|c|}
\hline \multirow[t]{2}{*}{ Pecahan } & \multicolumn{2}{|c|}{ Simbol } \\
\hline & Simbol Berbeda & Simbol Sama dan Seragam \\
\hline Rp 100.000 & $\begin{array}{l}\text { - Foto Pahlawan Nasional } \\
\text { DR. (H.C) Ir. Soekarno } \\
\text { DR. (H.C) Drs. Mohammad Hatta } \\
\text { - Tari Topeng Betawi } \\
\text { - Tempat Wisata Alam Raja Ampat } \\
\text { - Bunga Anggrek Bulan } \\
\text { - Motik Batik Sekar Jagad }\end{array}$ & \\
\hline Rp 50.000 & $\begin{array}{l}\text { - Foto Pahlawan Nasional } \\
\text { Ir. H. Djuanda Kartawidjaja } \\
\text { - Tari Legong } \\
\text { - Tempat Wisata Alam Taman Nasional } \\
\text { Komodo } \\
\text { - Bunga Jepun Bali } \\
\text { - Motif Batik Mega Mendung }\end{array}$ & \\
\hline Rp 20.000 & $\begin{array}{l}\text { - Foto Pahlawan Nasional } \\
\text { Dr. G.S.S.J Ratulangi } \\
\text { - Tari Gong } \\
\text { - Tempat Wisata Alam Derawan } \\
\text { - Bunga Anggrek Hitam } \\
\text { - Motif Batik Minahasa }\end{array}$ & $\begin{array}{l}\text { - Garuda Pancasila } \\
\text { - Teks Negara Kesatuan Republik Indonesia dan } \\
\text { Peta Indonesia } \\
\text { - Tanda Tangan Menteri Keuangan dan } \\
\text { Gubernur Bank Indonesia }\end{array}$ \\
\hline Rp 10.000 & $\begin{array}{l}\text { - Foto Pahlawan Nasional } \\
\text { Frans Kaisiepo } \\
\text { - Tari Pakarena } \\
\text { - Tempat Wisata Alam Taman Nasional } \\
\text { Wakatobi } \\
\text { - Bunga Cempaka Hutan Kasar } \\
\text { - Motif Yoniki }\end{array}$ & $\begin{array}{l}\text { - } \quad \text { Teks "Bank Indonesia" } \\
\text { - Teks "Seribu, Dua Ribu...Seratus Ribu } \\
\text { Rupiah" } \\
\text { - Teks "Dengan Rahmat Tuhan Yang Maha Esa } \\
\text { Negara Kesatuan Republik Indonesia } \\
\text { Mengeluarkan Rupiah Sebagai Alat } \\
\text { Pembayaran Yang Sah Dengan Nilai..." }\end{array}$ \\
\hline Rp 5.000 & $\begin{array}{l}\text { - Foto Pahlawan Nasional } \\
\text { Dr. K.H. Idham Chalid } \\
\text { - Tari Gambyong } \\
\text { - Tempat Wisata Alam Gunung Bromo } \\
\text { - Bunga Sedap Malam } \\
\text { - Motif Batik Akar Bakau }\end{array}$ & \\
\hline Rp 2.000 & $\begin{array}{l}\text { - Foto Pahlawan Nasional } \\
\text { Mohammad Hoesni Thamrin } \\
\text { - Tari Piring } \\
\text { - Tempat Wisata Alam Ngarai Sianok } \\
\text { - Bunga Jeumpa } \\
\text { - Motif Batik Gigi Balang }\end{array}$ & \\
\hline Rp 1.000 & $\begin{array}{l}\text { - Foto Pahlawan Nasional } \\
\text { Tjut Meutia } \\
\text { - Tari Tifa } \\
\text { - Tempat Wisata Alam Banda Neira } \\
\text { - Bunga Anggrek Larat } \\
\text { - Motif Batik Bungong Jeumpa } \\
\end{array}$ & \\
\hline
\end{tabular}


Berikut merupakan kesebelas simbol yang mengkonstruksi nasionalismer pada bagian depan

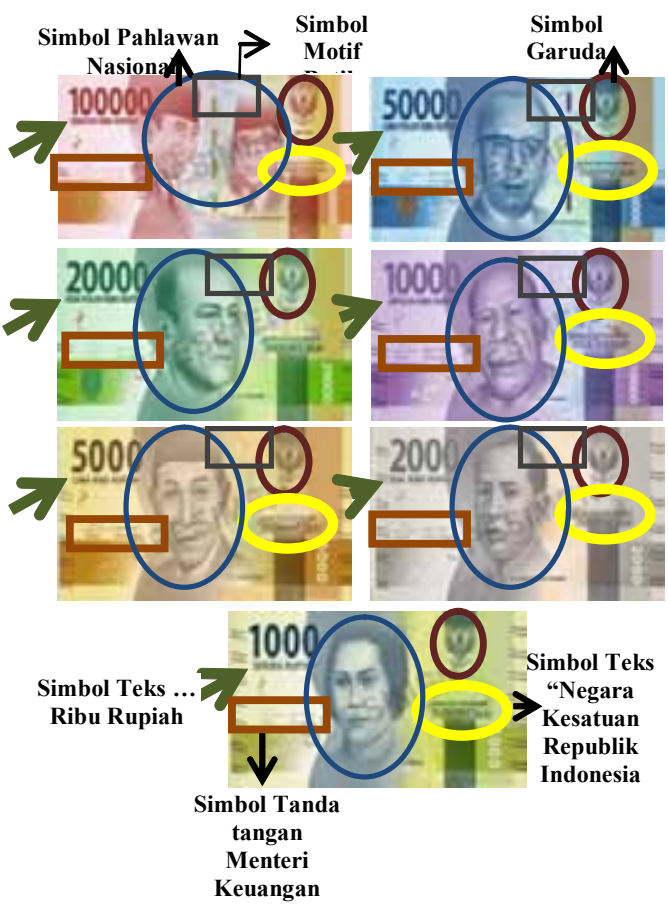

Gambar 2. Simbol Pada Bagian Depan Uang Rupiah Kertas Tahun Emisi 2016

\section{Makna Simbol Pada Uang Rupiah Kertas TE 2016}

Pada desain uang Rupiah kertas TE 2016, terdapat sebelas simbol yang memiliki maknanya masing-masing. Makna yang terdapat dalam sebuah simbol kemudian mampu menyampaikan sebuah pesan melalui apa yang ditampilkannya secara visual. Pesan-pesan inilah yang kemudian diwuhudkan melalui berbagai bentuk simbol. Pesan dalam komunikasi merupakan suatu rangsangan luar, pesan-pesan tersebut terdiri dari seperangkat tanda-tanda dan tanda-tanda ini kemudian ditanggapi didalam diri manusia dan menghasilkan suatu pemaknaan (Wibowo, 2013:120). Menurut Peirce simbol adalah tanda yang menunjukkan hubungan alamiah antara penanda dengan petandanya dengan hubungan berdasarkan konvensi atau kesepakatan bersama. (Yusran, Hafiar \& Sjoriada, 2017).

\section{Simbol Pahlawan Nasional}

Simbol pahlawan nasional merupakan simbol utama yang hadir pada bagian depan uang Rupiah dan belakang uang rupiah kertas TE 2016.

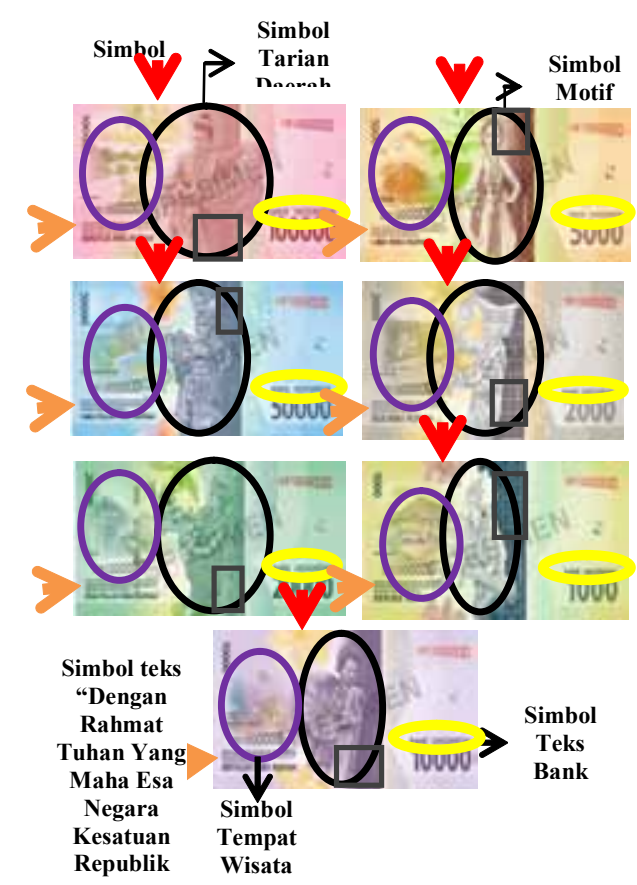

Gambar 3 Simbol Pada Bagian Belakang Uang Rupiah Kertas Tahun Emisi 2016

kertas TE 2016. Simbol pahlawan nasional memiliki makna sebagai seseorang yang menjadi bagian penting dari sejarah Indonesia. Hal ini dapat dilihat bahwa tidak semua orang dapat hadir dalam desain uang Rupiah kertas sekalipun mereka ialah sosok yang dikenal oleh masyarakat luas. Mereka yang hadir dalam uang Rupiah merupakan seseorang yang memiliki gelar pahlawan nasional yang ciri dan ketentuannya diatur oleh undangundang ataupun presiden yang telah gugur.

Menurut Undang-Undang Nomor 20 Tahun 2009 pahlawan nasional adalah gelar yang diberikan kepada warga negara Indonesia atau seseorang yang berjuang melawan penjajahan di wilayah yang sekarang menjadi wilayah Negara Kesatuan Republik Indonesia yang gugur atau meninggal dunia demi membela bangsa dan negara, atau yang semasa hidupnya melakukan tindakan kepahlawanan atau menghasilkan prestasi dan karya yang luar biasa bagi pembangunan dan kemajuan bangsa dan negara Republik Indonesia.

\section{Simbol Tarian Daerah}


Simbol tarian daerah merupakan salah satu hasil karya seni yang berasal dari berbagai daerah di Indonesia. Tarian daerah memiliki makna yang bergantung pada budaya dari masing-masing daerah. Keragaman budaya di Indonesia ini yang kemudian melahirkan berbagai tarian daerah dan ditampilkan dalam uang Rupiah kertas TE 2016. Oleh karenanya, simbol tarian daerah memiliki makna seni tari yang berasal dari beragam budaya di Indonesia. "Tari daerah merupakan suatu hasil ekspresi hasrat manusia akan keindahan dengan latar belakang atau sistem budaya masyarakat pemilik kesenian tersebut" (Widayati, 2012).

\section{Simbol Tempat Wisata Alam}

Simbol ini menampilkan tujuh objek wisata alam di berbagai daerah di Indonesia, diantaranya ialah Tempat Wisata Alam Raja Ampat, Taman Nasional Komodo, Derawan, Taman Nasional Wakatobi, Gunung Bromo, Ngarai Sianok, dan Banda Neira. Objek wisata alam tersebut menjadi salah satu kekayaan alam dalam sektor pariwisata yang dimiliki Indonesia. Oleh karenanya, simbol tempat wisata alam dimaknai sebagai kekayaan alam Indonesia yang dimanfaatkan sebagai objek wisata.

"Indonesia ditakdirkan memiliki kekayaan yang melimpah, baik berupa kekayaan alam maupun budayanya. Gugusan kepulauan yang berjumlah sekitar 18.110 pulau yang membentang dari barat ke timur merupakan kekayaan alam tersendiri dalam sektor pariwisata" (Somantri, 2012). Berbagai tempat wisata alam yang dihadirkan dalam desain uang Rupiah tentu menjadi kebanggan masyarakat Indonesia. "Our world is filled with such wonderful places and the countries host to them are proudly depicting their natural, cultural and architectural heritage on the currency notes" (mintageworld. com).

\section{Simbol Bunga}

Simbol bunga pada desain uang Rupiah kertas TE 2016 merupakan bunga yang menjadi ciri khas beberapa daerah di Indonesihaa. Ketujuh bunga dalam desain uang kertas TE 2016 ialah Bunga Anggrek Bulan, Jepun Bali, Anggrek Hitam, Cempaka Hutan Kasar, Sedap Malam,
Bunga Jeumpa, dan Anggrek Larat. Bunga yang mewakili sebuah daerah tidak hanya terbatas pada bunga-bunga endemik. Artinya ada beberapa latar belakang yang kemudian menjadikan sebuah daerah memilih salah satu jenis bunga sebagai representasi daerahnya. Oleh karenanya, simbol bunga dimaknai sebagai flora yang mencirikan daerah di Indonesia.

Berdasarkan Keputusan Presiden Republik Indonesia Nomor 4 Tahun 1993 Tentang Satwa dan Bunga Nasional, Negara dan bangsa Indonesia telah diberi karunia Tuhan Yang Maha Esa beragam jenis fauna dan flora, yang dalam khasanah fauna dan flora dunia, beberapa diantaranya bahkan sangat bersifat khas baik karena keberadaannya yang hanya terdapat di Indonesia, karena kelangkaannya, maupun karena latar belakang budaya yang melingkupinya.

\section{Simbol Motif Batik}

Motif batik merupakan beragam motif khas yang berasal dari berbagai kearifan lokal budaya di Indonesia yang menjadikannya memiliki makna tersendiri. Setiap motif batik selalu mempunyai latar belakang dan maknanya masing-masing (Lisbijanto, 2013: 55). Dengan melihat berbagai motif batik dalam uang Rupiah kertas, audience kemudian dapat memaknai bahwa motif batik sebagai warisan budaya Indonesia. Warisan budaya diartikan sebagai wujud karya masyarakat tradisional (adat) yang dapat berupa adat budaya, karya seni, dan teknologi yang telah turun-menurun digunakan sejak nenek moyang (Purwaningsih, 2005: 245).

\section{Simbol Garuda Pancasila}

Sebagai sebuah lambang negara, garuda pancasila mengandung nilai-nilai yang menjadi pedoman hidup dalam berbangsa dan bernegara. Nilai-nilai pancasila bagi bangsa Indonesia menjadi landasan dalam kehidupan kenegaraan yang tercermin dalam kelima silanya. Artinya lambang negara tidak dapat dipisahkan dari dasar negara pancasila (Kemenristekdikti, 2014: 42). Oleh karenanya, simbol garuda pancasila dalam uang Rupiah kertas TE 2016 dimaknai sebagai jati diri Indonesia yang memuat ideologi bangsa. 
Bagi bangsa Indonesia, jati diri tersebut dapat tersimpul dalam ideologi dan konstitusi negara, ialah Pancasila dan UUD 1945 (Kemenristekdikti, 2014: 31).

\section{Simbol Teks Negara Kesatuan Republik Indonesia dan Peta Indonesia}

Teks "Negara Kesatuan Republik Indonesia" merupakan teks yang berdampingan dengan gambar peta Indonesia. Teks ini dimaknai sebagai bentuk negara yang menegaskan wilayah Indonesia. "Negara kesatuan adalah bentuk negara yang mempunyai kemerdekaan dan kedaulatan atas seluruh wilayahnya atau daerah yang dipegang sepenuhnya oleh suatu pemerintah pusat" (Syafei, 2013).

\section{Simbol Tanda Tangan Menteri Keuangan dan Gubernur Bank Indonesia}

Pada uang Rupiah kertas TE 2016 terdapat simbol tanda tangan menteri keuangan Sri Mulyani dan Gubernur Bank Indonesia Agus D.W. Martowardojo. Menteri keuangan merupakan pimpinan tertinggi dalam tubuh pemerintahan yang berwenang dalam pengelolaan kebijakan fiskal. Hal inilah yang mendasari penempatan tanda tangan menteri keuangan sebagai bentuk perwakilan pemerintah yang dirasa sesuai untuk mendampingi tanda tangan Gubernur Bank Indonesia. "Berdasarkan Peraturan Menteri Keuangan RI Nomor 234/PMK.01/ 2015 Tentang Organisasi dan Tata Kerja Kementrian Keuangan dalam menjalankan tugasnya kementrian keuangan memiliki fungsi yang salah satunya ialah terkait pada perumusan, penetapan, dan pemberian rekomendasi kebijakan fiskal dan sektor keuangan" (kemenkeu.go.id).

Oleh karenanya, simbol tanda tangan menteri keuangan dan Gubernur Bank Indonesia pada uang Rupiah kertas TE 2016 dimaknai sebagai bentuk perwakilan pemerintah dan bank sentral di Indonesia yang berperan dalam pengelolaan mata uang resmi Indonesia. Pada fase ini, tergambar adanya proses komunikasi, karena "manusia melakukan kegiatan komunikasi dengan manusia lainnya memiliki tujuan untuk menyamakan makna akan suatu hal" (Antokosuryo, 2015).

\section{Simbol Teks "Bank Indonesia"}

Teks Bank Indonesia menjadi salah satu teks yang selalu menghiasi desain uang Rupiah. Bank Indonesia merupakan bank sentral di Indonesia. Oleh karenanya, teks "Bank Indonesia" pada desain uang Rupiah kertas TE 2016 dimaknai sebagai Bank sentral di Indonesia yang berwenang dalam mengeluarkan uang Rupiah. Bank sentral merupakan bank yang memiliki kewenangan dan kedudukan yang khusus dan berbeda dengan bank lainnya. Bank sentral menjadi lembaga keuangan yang memiliki hak terhadap pengelolaan mata uang negara.

"Berdasarkan Undang-Undang Nomor 3 Tahun 2004 Tentang Perubahan Atas Undang-Undang Nomor 23 Tahun 1999 Tentang Bank Indonesia, Bank Sentral adalah lembaga negara yang mempunyai wewenang untuk mengeluarkan alat pembayaran yang sah dari suatu negara, merumuskan dan melaksanakan kebijakan moneter, mengatur dan menjaga kelancaran sistem pembayaran, mengatur dan mengawasi perbankan, serta menjalankan fungsi sebagai lender of the last resort"'(bi.go.id).

Dalam hal ini bank yang memiliki kewenangan sebagai bank sentral ialah Bank Indonesia. Kedudukan Bank Indonesia sebagai bank sentral tersebut tertera dalam undang-Undang Nomor 3 Tahun 2004 Tentang Perubahan Atas UndangUndang Nomor 23 Tahun 1999 Tentang Bank Indonesia.

Teks "Seribu, Dua Ribu...Seratus Ribu Rupiah"

Simbol teks "Seribu, Dua Ribu, Lima Ribu... Seratus Ribu Rupiah" merupakan penjelas nilai nominal pada setiap lembaran uang Rupiah. Dalam penyebutan nilai nominal uang Rupiah kertas, Bank Indonesia menggunakan Bahasa Indonesia yang merupakan bahasa resmi negara. Untuk itu, simbol teks "Seribu, Dua Ribu, Lima Ribu, Seratus Ribu Rupiah" dimaknai sebagai penggunaan bahasa resmi negara dalam penyebutan nilai nominal pada uang Rupiah kertas.

Pada Undang-Undang Nomor 24 Tahun 2009 disebutkan bahwa Bahasa Indonesia sebagai bahasa resmi negara berfungsi sebagai bahasa resmi 
kenegaraan, pengantar pendidikan, komunikasi tingkat nasional, pengembangan kebudayaan nasional, transaksi dan dokumentasi niaga, serta sarana pengembangan dan pemanfaatan ilmu pengetahuan, teknologi, seni, dan bahasa media massa.

\section{Simbol Teks "Dengan Rahmat Tuhan Yang Maha Esa..."}

Teks "Dengan Rahmat Tuhan Yang Maha Esa Negara Kesatuan Republik Indonesia Mengeluarkan Rupiah Sebagai Alat Pembayaran Yang Sah Dengan Nilai..." merupakan teks yang memiliki makna bahwa Indonesia secara hukum berdasarkan pada ketuhanan yang maha esa dan memiliki Rupiah sebagai mata uang resmi negara. Hal ini dapat dilihat dari beberapa frasa pada teks tersebut yang menjelaskan nilai-nilai ketuhanan, bentuk negara, dan kedudukan uang rupiah sebagai alat pembayaran yang sah. Frasa Dengan Rahmat Tuhan Yang Maha Esa pada uang rupiah kertas menjadi frasa yang mecerminkan rasa syukur bangsa Indonesia karena mampu megeluarkan uang Rupiah sebagai alat pembayaran yang sah. "Sebagai sebuah simbol kedaulatan bangsa, Indonesia mengalami perjalanan yang cukup panjang hingga akhirnya mampu mengeluarkan mata uang negara" (padangmedia.com).

Sementara itu frasa Negara Kesatuan Republik Indonesia menjelaskan bentuk negara dan pemerintahan yang sesuai dengan peraturan perundang-undangan. Dalam Undang-Undang dasar 1945 pasal 1 dijelaskan bahwa Negara Indonesia ialah Negara kesatuan yang berbentuk Republik. Kehadiran frasa NKRI kemudian menjadi bentuk penegasan bahwa uang Rupiah merupakan uang NKRI. Berdasarkan apa yang tertuang dalam pasal 1 UU No.7 Tahun 2011 Tentang Mata Uang dijelaskan bahwa Mata Uang adalah uang yang dikeluarkan oleh Negara Kesatuan Republik Indonesia yang selanjutnya disebut Rupiah. Uang NKRI ini pada undang-undang yang sama selanjutnya disebutkan sebagai alat pembayaran yang sah di Indonesia. Menurut Gubernur Bank Indonesia, Agus DW Martowardojo, "Rupiah merupakan alat pembayaran yang sah dan wajib digunakan pada setiap transaksi di wilayah NKRI" (kompas.com).

\section{Simbol Pada Desain Uang Rupiah Kertas Mengkonstruksi Makna Nasionalisme}

Sebagai mata uang resmi negara Indonesia, uang Rupiah kertas menjadi media yang kemudian menampilkan berbagai simbol yang memiliki makna yang mendalam bagi bangsa Indonesia. Simbol ini biasanya berhubungan dengan sejarah nasional atau budaya khas yang berasal dari berbagai daerah di Indonesia.

"Pada setiap mata uang kertas baru yang beredar, desain grafis mata uang kertas Indonesia membawa inti komunikasi yaitu pesan-pesan berupa isu politik, sosial, ekonomi dan kebudayaan sehingga informasi kepada rakyat sebagai sasaran pesan sampai kepada objeknya" (Banindro, 2012).

Berbagai simbol inilah yang memiliki kekuatan dalam menyampaikan pesan nasionalisme. Nasionalisme menjadi sebuah ideologi penting bagi masyarakat Indonesia yang multikultural dan tersebar pada berbagai daerah. "Nasionalisme merupakan suatu ikatan sadar yang dimiliki bersama oleh sekelompok orang yang memiliki kesamaan bahasa, kebudayaan dan sejarah yang ditandai dengan kejayaan dan penderitaan bersama dan saling terikat dalam suatu negeri tertentu" (Perry dalam Alfaqi, 2016).

Dalam penelitian ini, nasionalisme dirumuskan sebagai suatu gerakan ideologis untuk mencapai dan mempertahankan otonomi, kesatuan, dan identitas bagi suatu populasi yang sejumlah anggotanya bertekad untuk membentuk bangsa yang potensial (Smith, 2003: 33). Dari pengertian nasionalisme tersebut dapat disimpulkan bahwa sebagai sebuah ideologi, nasionalisme mengandung tiga unsur yaitu otonomi (autonomous), kesatuan (unity), dan identitas (identity).

Autonomous merupakan pemikiran yang menganggap bahwa bangsa adalah entitas komunitas yang mampu berdiri sendiri secara utuh dengan peraturan yang dimilikinya (Smith, 2003: 31).Sementara itu, unity atau kesatuan merupakan unsur dalam pemikiran nasionalisme yang menjelaskan bahwa suatu bangsa merupakan suatu komunitas yang hidup dalam kesatuan sejarah 
atau nasib yang sama (Smith, 2003: 32). Terakhir unsur dalam nasionalisme ialah identity. Unsur ini menjadi sebuah unsur pembeda antara suatu bangsa yang biasanya memiliki kaitan dengan karakter budaya yang khas (Smith, 2003: 33).
Untuk mengetahui konstruksi makna nasionalisme, maka peneliti mengelompokkan simbol-simbol yang hadir dalam uang Rupiah kertas kedalam tiga unsur tersebut. (Lihat Bagan 1).

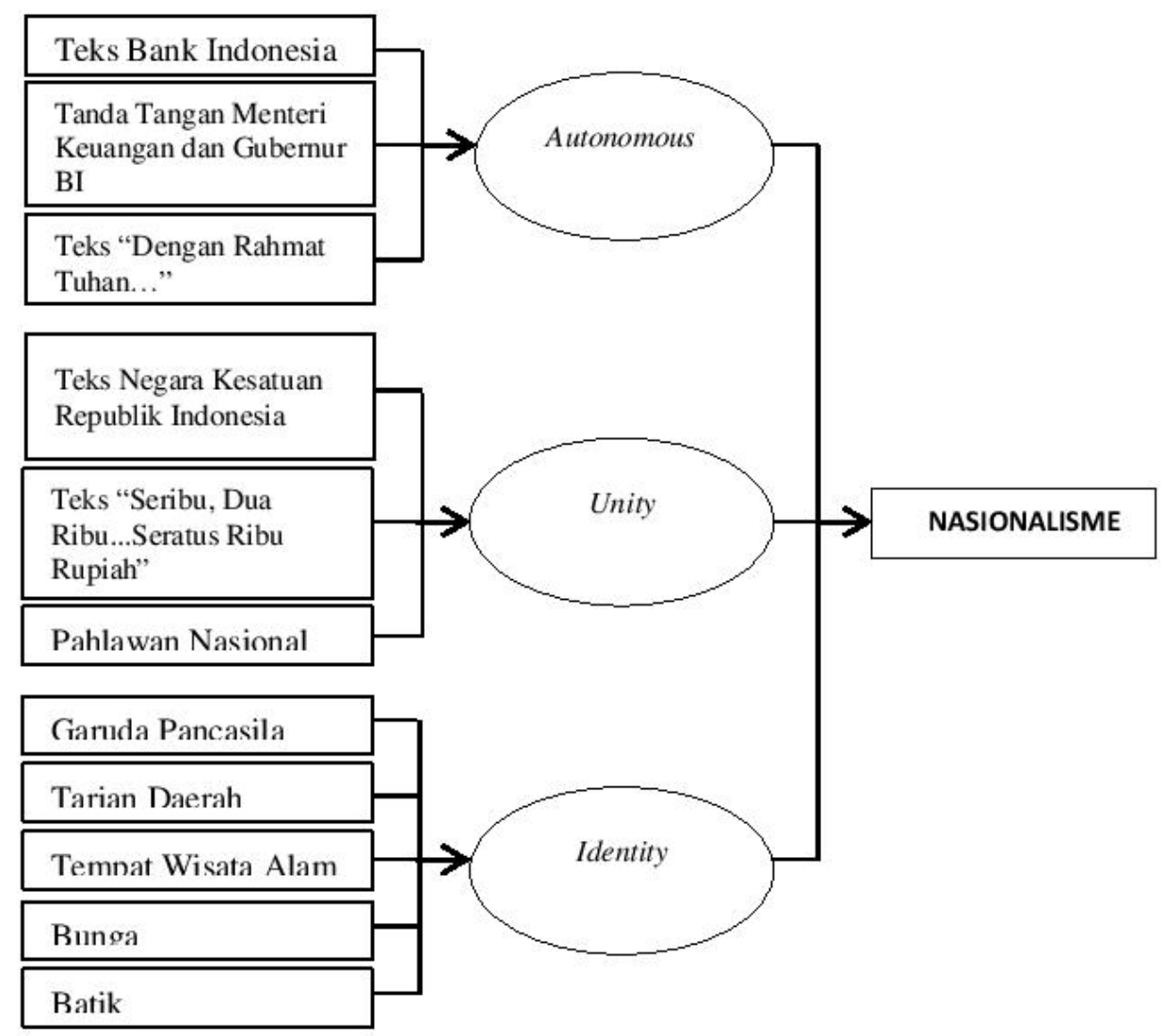

Bagan 1 Simbol Pada Desain Uang Rupiah Kertas Mengkonstruksi Nasionalisme

\section{Simbol Pahlawan Nasional}

Pada uang Rupiah kertas TE 2016 terdapat simbol pahlawan nasional yang ditampilkan dengan gambar seorang tokoh yang menjadi representasi mental yang terdapat dalam pikiran audience (Vera, 2014: 21). Untuk itu, gambar tokoh yang hadir dalam uang Rupiah kertas TE 2016 disepakati sebagai seorang pahlawan nasional.Pahlawan nasional jika dikaitkan dengan sejarah Indonesia merupakan sosok penting dalam memerdekakan bangsa ini. Perjuangan dan pengorbanan para pahlawan nasional dilakukan demi kepentingan bangsa Indonesia. "Pahlawan nasional menjadi sosok yang wajib dikenang sebagai bagian dari sejarah yang memperjuangkan bangsa”. (Mirnawati, 2012: 67).Oleh karenanya, kehadiran pahlawan nasional dalam uang kertas menjadi simbol yang ditujukan untuk meningkatkan kesadaran nasional masyarakat Indonesia. "Sejarah nasional fungsinya sangat fundamental untuk menciptakan kesadaran nasional yang pada gilirannya memperkokoh solidaritas nasional" (Sardiman, 2011).

Dengan begitu, simbol pahlawan nasional mengkonstruksikan makna unity. Masyarakat Indonesia merupakan bagian bangsa ini yang memiliki kesamaan atas sejarahnya. Oleh karena itu, kesamaan sejarah inilah yang kemudian mampu menyatukan masyarakat Indonesia yang berasal dari berbagai latar belakang dan meningkatkan semangat nasionalisme. Kesadaran sejarah menjadi salah satu faktor yang berperan penting dalam 
menumbuhkan semangat nasionalisme (Kartodirjo dalam Aman, 2009).

\section{Simbol Tarian Daerah}

Simbol tarian daerah ditampilkan dengan gambar penari. Gambar penari menjadi gambar yang langsung ditangkap oleh indera penglihatan dan belum memiliki kaitan dengan pemikiran yang hadir dalam benak individu. Dengan begitu gambar penari berperan sebagai qualisign. "A sign presents itself, but at this initial stage it is part of the 'independently real' world as a raw physical or a mental entity, a qualisign" (Merrell dalam Napita, 2015).Jika kemudian gambar penari dalam uang Rupiah dihubungkan dengan kenyataan, maka audience akan menafsirkannya sebagai seni tari yang berasal dari berbagai budaya di Indonesia. "Ragam kebudayaan juga menyandang ragam kesenian daerah yang berbeda-beda" (Kosasi, 2016).

Namun ketika gambar penari dikaitkan dengan konvensi sosial maka gambar tersebut menjadi simbol yang menunjukkan ciri khas negara Indonesia. "Setiap negara di dunia memiliki kebudayaan yang menjadi identitas sekaligus ciri khas yang membedakan antara suatu negara dengan negara yang lain". (Azzati dan Handayani, 2015).Oleh karenanya simbol tarian daerah menjadi simbol yang mengkonstruksi makna identity. Identitas inilah yang menjadi kebanggan bangsa Indonesia. "Dalam kerangka nasionalisme diperlukan sebuah kebanggaan untuk menampilkan identitasnya sebagai suatu bangsa" (Kusumawardani dan Faturochman, 2004).

\section{Simbol Tempat Wisata Alam}

Simbol tempat wisata alam ditampilkan dengan gambar keadaan alam yang indahdalam benak audience. Hal ini yang menjadikan keadaan alam yang indah ditafsirkan sebagai simbol tempat wisata alam. "Tempat wisata alam pada dasarnya menyuguhkankeindahanpanoramaalam"(Soetopo, 2011: 6).Ketika audience menghubungkan gambar keadaan alam yang indah dengan sebuah realitas kekayaan alam yang dimiliki Indonesia dan dimanfaatkan sebagai objek wisata alam, maka audience kemudian akan menghubungkan realita tersebut dengan sebuah konvensi sosial. Konvensi sosial tersebut memberikan penjelasan terhadap sebuah keindahan alam Indonesia yang khas. "Obyek wisata di Indonesia mempunyai potensipotensi yang menjadikan bangsa Indonesia mempunyai ciri khas yang tidak di miliki oleh negara lain" (Kasmaningrum, 2008). Untuk itu, simbol tempat wisata alam yang ditampilkan dalam uang Rupiah kertas menjadi kekhasan dari bangsa Indonesia yang mengkonstruksi makna identity. "Identitas menjadi hal yang tidak terlepas dari nasionalisme yang berhubungan dengan jati diri bangsa" (Rahayu, 2007: 56).

\section{Simbol Bunga}

Simbol bunga ditunjukkan dengan gambar flora pada uang rupiah kertas. Gambar flora yang nampak terlihat jelas oleh audience ketika melihat uang Rupiah kertas tersebut merupakan sebuah qualisign. Qualisign menjadi tanda yang murni - Artinya gambar tersebut berdiri sebagaimana adanya tanda. "A qualisign pure quality without there yet existing any relation to anything els or even consciousness of the quality on the part of some semiotic agen"(Merrelll, 1997: 168). Jika kemudian gambar flora dihubungkan dengan kenyataan, maka gambar tersebut menjadi sebuah eksistensi dari flora yang identik dengan daerahdaerah di Indonesia. Inilah yang kemudian disebut sebagai sinsign. Dimana sinsign memiliki beberapa karakteristik yang terdapat dalam qualisign. But at the same time, the sinsign involves a "peculiar kind" of qualisign (Koshul, 2014: 114). Namun ketika dikaitkan dengan konvensi sosial maka gambar flora pada uang rupiah kertas menjadi gambar yang menunjukkan flora khas Indonesia. Oleh karenanya, Dari pernyataan-pernyataan tersebut maka didapatkan sebuah argument bahwa gambar flora pada uang Rupiah kertas berupa bunga menunjukkan keragaman jenis bunga yang mencirikan daerah di Indonesia yang menjadi kekhasan bangsa dan menunjukkan identitas bangsa.

Identitas merupakan sebuah ciri khas yang datang dari dalam negara yang menjadi pembeda dengan negara lainnya di dunia. Sebagai negara dengan iklim tropis, Indonesia menjadi negara yang mampu menjadi tempat tumbuhnya berbagai macam jenis 
bunga. Inilah yang kemudian menjadi kebanggan bagi masyarakat Indonesia. "Some of these ornamental plants are natives to Indonesia while others are from other countries and climate zones but grow well in Indonesia" (Manurung, 2011). Bunga-bunga yang merupakan ciri dari daerah-daerah di Indonesia tersebut menjadi sebuah kekhasan Indonesia. Berdasarkan Keputusan Presiden Republik Indonesia Nomor 4 Tahun 1993 disebutkan bahwa kekhasan beberapa flora dan fauna di Indonesia pada dasarnya merupakaan kebanggan nasional. Kekhasan tersebutlah yang kemudian menjadi identitas bangsa yang menjadi karakter pembeda Indonesia dengan negara lainnya. Oleh karenanya, simbol bunga pada uang Rupiah kertas TE 2016 mengkonstruksi makna Identity.

\section{Simbol Motif Batik}

Simbol motif batik digambarkan dengan beragam corak yang dihadirkan pada desain uang Rupiah kertas. Ragam corak tersebut memiliki nilai-nilai filosofis yang disesuaikan dengan kearifan budaya lokal.

"Motif batik tidak hanya menciptakan sesuatu yang indah dipandang mata, melainkan juga memberi makna yang erat hubungannya dengan falsafah hidup yang mereka hayati. Motif batik yang diciptakan syarat akan pesan dan harapan yang tulus, luhur, dan damai serta membawa kebaikan bagi si pemakainya, yang divisualisasikan secara simbolis" (Qoimah, 2012).

Oleh karenanya, simbol motif batik dimaknai sebagai warisan budaya Indonesia. "Batik sangat erat dengan nilai budaya masyarakat sehingga batik tidak saja sebagai hasil produksi semata, tetapi juga merupakan hasil budaya dari suatu masyarakat" (Lisbijanto, 2013: 7). Sebagai hasil dari sebuah tradisi, motif batik menjadi budaya yang khas dengan Indonesia. Dengan begitu, simbol motif batik menjadi simbol yang mengkonstruksi makna identity. "Batik adalah ekspresi budaya yang memiliki makna simbolis dan nilai estetika yang tinggi bagi masyarakat Indonesia. Keunikan yang indah itu merupakan salah satu pembentuk karakter bangsa Indonesia yang membedakan kita dengan bangsa lain sehingga dapat menjadi identitas dan jati diri bangsa" (www.uph.edu).

\section{Simbol Garuda Pancasila}

Simbol garuda pancasila divisualisasikan dengan gambar burung garuda pada uang Rupiah kertas. Gambar tersebut merupakan tanda qualisign yang apabila dikaitkan dengan benak audience gambar tersebut identik dengan garuda pancasila. Ide mengenai garuda pancasila ini tidak terlepas dari simbol-simbol sila pancasila yang hadir di dalamnya.Berbagai visualisasi garuda pancasila memiliki arti yang dianggap sesuai dengan kepribadian bangsa. "Makna garuda pancasila sangat relevan dengan kondisi bangsa Indonesia yang terdiri dari berbagai macam suku, ras, budaya, adat, bahasa, dan negara" (www. bin.go.id). Hal inilah yang kemudian menjadikan garuda pancasila sebagai sebuah kekhasan bagi Indonesia yang membedakan dengan bangsabangsa lainnya di dunia. Kekhasan tersebut kemudian menjadi identitas nasional bangsa. "Identitas nasional Indonesia merupakan ciri-ciri yang dapat membedakan negara Indonesia dengan negara lainnya dan disebutkan dalam konstitusi Indonesia yaitu UUD 1945 pasal 35-36 C yang salah satu diantaranya ialah garuda pancasila" (Pasaribu, 2013).

\section{Simbol Teks Negara Kesatuan Republik Indonesia dan Peta Indonesia}

Frasa Negara Kesatuan Republik Indonesia ditampilkan dalam bentuk teks yang berdampingan dengan gambar peta dalam uang Rupiah kertas. Tanda yang menunjukkan teks yang berdampingan dengan gambar peta tersebut menjadi qualisign yang mampu ditangkap oleh alat indera penglihatan. "[...] according to the sign in itself is a mere quality, is an actual existence, or is a general law" (Peirce dalam Koshul, 2014: 113). Namun jika dikaitkan dengan realitas, teks ini memiliki makna sebagai sebuah frasa yang menunjukkan bentuk negara Indonesia yang menegaskan wilayah Indonesia. "Negara Indonesia adalah Negara yang berbentuk Kesatuan (unitary state). Kekuasaan asal berada di pemerintah pusat, namun kewenangan (authorithy) pemerintah pusat ditentukan batas-batasnya dalam Undang-Undang Dasar dan undang-undang" 
(Asshiddique, 2001: 28).

Penetapan bentuk negara tersebut tidak terjadi begitu saja, artinya terdapat proses yang panjang hingga kemudian negara kesatuan dianggap sebagai bentuk negara yang paling ideal. "Negara kesatuan menjadi bentuk negara yang ideal bagi Indonesia sebab bentuk negara ini mampu mengakomodasi ide persatuan sebuah bangsa yang plural atau majemuk yang dilihat dari berbagai latar belakang" (Lubis, 2016). Oleh karenanya, simbol teks Negara Kesatuan Republik Indonesia mengkonstruksi makna unity atau kesatuan yang menjadi salah satu unsur nasionalisme.

\section{Simbol Tanda Tangan Menteri Keuangan dan Gubernur Bank Indonesia}

Pada TE 2016, tanda tangan yang hadir dalam desain uang Rupiah kertas ialah menteri keuangan dan gubernur Bank Indonesia. Jika melihat hubungan trikotominya, gambar tanda tangan merupakan sebuah qualisign yang kemudian merujuk pada tanda tangan menteri keuangan dan gubernur Bank Indonesia sebagai sebuah ikon. Dari hubungan tersebut selanjutnya terdapat sebuah kemungkinan tanda yang akan ditafsirkan audience yaitu gambar tanda tangan menteri Keuangan dan Gubernur Bank Indonesia tertera pada uang Rupiah kertas.Kemungkinan penafsiran gambar tanda tangan tersebut berlaku pada trikotomi pertama.

Namun ketika dihubungkan dengan kategori secondness, maka gambar tersebut akan dihubungkan dengan realitas bahwa pemerintah dan Bank Indonesia merupakan pihak yang memiliki peran dalam pengelolaan mata uang negara, Rupiah."Kementerian Keuangan dan Bank Indonesia telah menyepakati nota kesepahaman (Memorandum of Understanding) mengenai koordinasi pelaksana Undang-Undang Nomor 7 Tahun 2011 tentang Mata Uang". Oleh karenanya, simbol tanda tangan Menteri Keuangan dan Gubernur Bank Indonesia mengkonstruksi makna autonomous sebagai unsur dari nasionalisme yang menggambarkan bahwa Indonesia memiliki kewenangan sendiri tanpa campur tangan negara lain dalam pengelolaan mata uang resmi negara. Dimana kehadiran simbol tanda tangan tersebut menjadi amanat Undang-Undang Nomor 7 Tahun 2011 tentang mata uang.

\section{Simbol Teks Bank Indonesia}

Teks Bank Indonesia diartikan sebagai sebuah nama bank yang selalu hadir dalam desain uang Rupiah. Kehadiran teks tersebut tentu tidak terlepas dari tugas dan wewenang Bank Indonesia sebagai Bank Sentral sebagaimana yang tertulis dalam Undang-Undang Nomor 23 Tahun 1999 Tentang Bank Indonesia (bi.go.id). Oleh karenanya, simbol teks Bank Indonesia dimaknai sebagai bank sentral di Indonesia yang berwenang dalam mengeluarkan uang rupiah.

Dari penjelasan diatas maka simbol teks Bank Indonesia merupakan simbol yang mengkonstruksi makna autonomous. Unsur autonomous ini menjelaskan bahwa negara memiliki hukum atau aturan tersendiri dalam pengelolaan mata uang negara melalui bank sentral di Indonesia. Pada prinsipnya, "Manusia tidak pasif dalam menerima rangsangan stimuli, sebaliknya manusia aktif berinteraksi dan merespon suatu pesan dalam memaknai suatu objek atau fenomena" (Artawan, Shintadewi, \& Budiana, 2016) termasuk memaknai simbol dalam uang kertas rupiah.

\section{Simbol Teks "Seribu, Dua Ribu...Seratus Ribu Rupiah"}

Teks “Seribu, Dua Ribu... Seratus Ribu Rupiah" ditampilkan dalam frasa yang tersusun atas huruf dan terdapat dibawah nilai nominal uang Rupiah kertas. Tanda inilah yang kemudian menjadi tanda qualisign dari teks "Seribu, Dua Ribu...Seratus Ribu Rupiah". "Qualisign are firstness as a sign of pure, unbounded possibility, quality, freedom and spontaneity" (Koshul, 2014: 114). Teks tersebut menjelaskan nilai nominal uang Rupiah kertas pada masing-masing pecahan dengan menggunakan bahasa resmi negara."Bahasa Indonesia merupakan bahasa yang diakui sebagai bahasa resmi negara Indonesia (Prihartini, 2015: 4).Oleh karenanya, Bahasa Indonesia menjadi bahasa persatuan yang menyatukan masyarakat Indonesia yang berasal dari berbagai budaya. "Penggunaan bahasa Indonesia sebagai bahasa resmi negara merupakan alat pemersatu ragam bahasa dan kebudayaan 
yang mampu menjadi penghubung antarbudaya dan antardaerah"(Prihartini, 2015: 5). Dari premis-premis tersebut maka simbol teks "Seribu, Dua Ribu, Lima Ribu...Seratus Ribu Rupiah" mengkonstruksi makna unity.

\section{Simbol Teks "Dengan Rahmat Tuhan Yang Maha Esa Negara Kesatuan Republik Indonesia Mengeluarkan Uang Rupiah Sebagai Alat Pembayaran yang sah Dengan Nilai ..."}

Kalimat "Dengan Rahmat Tuhan Yang Maha Esa...." ditampilkan dalam bentuk teks pada uang Rupiah kertas yang tertera disamping kiri gambar penari. Apa yang ditampilkan tersebut merupakan aspek visual yang kemudian menjadi qualisign. Jadi teks pada uang Rupiah kertas yang tertera disamping kiri gambar penari merupakan sebuah qualisign. Merrell menyebutkan bahwa Qualisign merupakan, "pure sensation before there is consciousness of sensation" (Merrelll, 1997 : 134). Qualisign tersebut memiliki relasi dengan kalimat "Dengan Rahmat Tuhan Yang Maha Esa...." yang kemudian menjadi kemungkinan tanda yang dinamakan Rheme.

Jika dikaitkan dengan realitas maka kalimat "Dengan Rahmat Tuhan Yang Maha Esa..." merupakan penjelasan atas negara Indonesia yang berdasarkan kepada tuhan yang maha esa seperti yang tertera dalam undang-undang. Dengan begitu qualisign yang dihubungkan dengan realitas akan menghasilkan tanda berupa sinsign. Dari relasi tersebut maka "teks pada uang Rupiah kertas yang tertera disamping kiri gambar penari menunjukkan bahwa Indonesia secara hukum berdasarkan pada ketuhanan yang maha esa dan mampu mengeluarkan Rupiah sebagai mata uang resmi” merupakan sebuah sinsign. "[...] according as the relation of the sign to its object consist in the sign"s having some character on itself, or in some existential relation to that object, or in its relation to the interpretant" (Koshul, 2014 : 113). Realitas ini didasarkan pada Undang-Undang Dasar 1945 yang menyebutkan bahwa negara Indonesia berdasar atas ketuhanan yang maha esa.

Realitas tersebut memberikan relasi terhadap kalimat "Dengan Rahmat Tuhan Yang Maha Esa..." yang menjadi sebuah decisign memiliki makna yang berkembang. Artinya masyarakat akan melihat bahwa teks yang berbentuk kalimat tersebut merupakan sebuah rangkaian huruf. Teks adalah sederetan kata atau kalimat yang menjelaskan suatu barang atau jasa untuk tujuan tertentu (Baskara, 2011). Sementara kata sendiri menjadi kumpulan huruf yang memberi sebuah makna. "Bentuk/rupa huruf dalam suatu kumpulan huruf (font) dapat memberi kesan tersendiri yang dapat mempermudah khalayak menerima pesan atau gagasan yang terdapat pada sebuah kata atau kalimat"79.

Oleh karenanya dari premis-premis diatas terdapat sebuah argument "Teks pada uang Rupiah kertas yang tertera disamping kiri gambar penari merupakan rangkaian huruf yang membentuk kalimat "Dengan Rahmat Tuhan Yang Maha Esa..." dan menyatakan bahwa Indonesia berdasarkan pada nilai-nilai ketuhanan memiliki Rupiah sebagai mata uang resmi negara". Dari argument tersebut maka simbol teks "Dengan Rahmat Tuhan Yang Maha Esa..." mengkonstruksi makna autonomous yang menjelaskan bahwa Indonesia merupakan negara yang dapat berdiri secara utuh tanpa campur tangan bangsa lain. Hal ini dapat dilihat dari Indonesia yang memiliki hukum sendiri dalam mengatur negaranya yang telah dijelaskan dalam premis diatas. Lebih jelasnya teks "Dengan Rahmat Tuhan Yang Maha Esa Negara Kesatuan Republik Indonesia..” disebutkan dalam pasal 5 Undang-Undang Nomor 7 Tahun 2011 Tentang Mata Uang yang menjelaskan mengenai ciri umum desain uang Rupiah. Oleh karenanya, teks ini menjadi bagian penting yang hadir di setiap desain uang Rupiah kertas.

\section{SIMPULAN}

Dalam desain uang Rupiah kertas TE 2016 terdapat sebelas simbol utama yang mengonstruksi makna nasionalisme. Lima simbol diantaranya berbeda pada setiap pecahannya yaitu; (1)Pahlawan Nasional, (2)Tarian Daerah, (3)Tempat Wisata Alam, (4)Bunga, (5)Motif Batik. Sementara itu enam simbol lainnya sama dan seragam pada setiap pecahan; (6)Garuda Pancasila, (7)Teks Negara Kesatuan Republik Indonesia dan Peta Indonesia, (8) Tanda Tangan Menteri Keuangan dan Gubernur 
Bank Indonesia, (9)Teks Bank Indonesia (10)Teks "Seribu, Dua Ribu, Lima Ribu...Seratus Ribu Rupiah", (11)Teks "Dengan Rahmat Tuhan Yang Maha Esa...".

Adapun makna dari simbol garuda pancasil adalah jati diri Indonesia yang memuat ideologi bangsa, makna simbol teks Negara Kesatuan Republik Indonesia dan Peta Indonesia adalah bentuk negara yang menegaskan wilayah Indonesia, makna simbol teks Bank Indonesia adalah bank sentral di Indonesia yang berwenang dalam mengeluarkan uang Rupiah, makna simbol teks "Seribu, Dua Ribu..Seratus Ribu Rupiah" ialah penggunaan bahasa resmi negara dalam penyebutan nilai nominal uang Rupiah kertas, makna simbol tanda tangan Menteri Keuangan dan Gubernur Bank Indonesia ialah bentuk perwakilan pemerintah dan bank sentral Indonesia yang berperan dalam pengelolaan mata uang resmi Indonesia, makna simbol teks "Dengan Rahmat Tuhan Yang Maha Esa..." ialah kalimat yang menyatakan bahwa Indonesia secara hukum merupakan negara yang berdasarkan pada ketuhanan yang maha esa dan memiliki Rupiah sebagai mata uang resmi.

Simbol lainnya seperti pahlawan nasional memiliki makna seseorang yang menjadi bagian penting dari sejarah Indonesia, makna simbol tarian daerah adalah seni tari yang berasal dari berbagai budaya di Indonesia, makna simbol tempat wisata alam ialah kekayaan alam yang dimanfaatkan sebagai objek wisata, makna simbol bunga ialah keragaman jenis bunga yang mencirikan daerah di Indonesia, dan makna simbol motif batik ialah warisan budaya Indonesia.

Kesebelas simbol pada uang Rupiah kertas TE 2016 memiliki makna yang mampu mengkonstruksi makna Autonomous, Unity, dan Identity yang menjadi unsur dalam nasionalisme. Makna Autonomous dikonstruksikan melalui simbol teks "Bank Indonesia", simbol tanda tangan Menteri Keuangan dan Gubernur Bank Indonesia, serta teks "Dengan Rahmat Tuhan Yang Maha Esa...". Sementara itu makna unity dikonstruksikan melalui simbol teks Negara Kesatuan Republik Indonesia dan Peta Indonesia, simbol teks "Seribu, Dua Ribu...Seratus Ribu Rupiah", dan simbol pahlawan nasional. Kemudian makna identity terkonstruksi melalui simbol garuda pancasila, simbol tarian daerah, simbol tempat wisata alam, simbol bunga, dan simbol motif batik.

\section{DAFTAR PUSTAKA}

Aman. (2009). Kesadaran Sejarah Dan Nasionalisme: Pengalaman Indonesia. E-Jurnal Universitas Negeri Yogyakarta. Diakses dari http:// staffnew.uny.ac.id/upload/132303695/ penelitian/B-22+KESADARAN+ SEJARAH+DAN+NASIONALISME.pdf Pada 10 Juni 2017

Andrew. (2014). At The Intersection of Place Branding and Political Branding: Canadian Banknote Iconography and Political Priorities. e-Journal University of Ottawa, Kanada. Diakses dari https://www. ruor.uottawa.ca/bitstream/10393/32049/1/ CHAMPAGNE\%2 C\%20Andrew \%20 20145.pdf Pada 7 Maret 2017

Antokosuryo, A. (2015). Representasi sosok superhero hulk dalam iklan lifebuoy handwash versi changing colour. Wacana, 14(3), 241-265.

Artawan, G. A. W. M., Shintadewi, E. A., \& Budiana, H. R. (2016). Makna kegiatan unilever future leaders league bagi para peserta. Jurnal Profesi Humas, 1(1), 1-11.

Asshiddiqie, J. (2001). Konstitusi Dan Konstitusionalisme. Jakarta konstitusi press

Azzanti dan Handayani. (2015). Akulturasi Budaya Arsitektur Tiongkok Dengan Jawa Di Kawasan Kelenteng Sam Po Kong Semarang. Tugas Akhir Universitas Gadjah Mada. Diakses dari http://etd.repository. ugm.ac.id/downloadfile/85644/potongan/ D3-2015-336190-introduction.pdf. Pada 29 Mei 2017

Banindro, B. (2012). Tinjauan Visual Gambar Uang Kertas Indonesia. e-Journal Institut Seni Yogyakarta. Diakses darinirmana. petra.ac.id/index.php/dkv /article 
download/18001/17916 Pada 16 Juni 2017

Fiske, J. (2012). Pengantar Ilmu Komunikasi: edisi ketiga. Jakarta: Rajagrafindo Persada

Hafiar, H., Mahameruaji, J. N., \& Rahmawan, D. (2017). Analisis semiotika pada cover novel trilogi karya Vira Safitri. Jurnal Nomosleca, 3(April).

Helleiner, E. (2005). "Nation-States and Money: The Past, Present and Future of National Currencies". Diakses dari https://www. scribd.com/document/355487275/NationStates-and-Money-the-Past-Emily-Gilbert Pada 6 Desember 2016

Kasmaningrum, N. (2008). Potensi dan Pengembangan Obyek Wisata Goa Gong di Kabupaten Pacitan. Diakses dari http://eprints.uns. ac.id/9234/1/79272107200901271.pdf Pada 11 Juni 2017

Kemenristekdikti. (2014). Buku Modul Kuliah Kewarganegaraan. Diakses dari http:// kuliahdaring.dikti.go.id/lms1/pluginfile. $\mathrm{php} / 15832 / \mathrm{mod}$ resource/content $/ 2 /$ BAB\%20II\%20Identitas_PDITT.pdf Pada 31 Mei 2017

Koshul, B. (2014). Max Weber and Charles Peirce: At the Crossroads of Science,Philosophy, and Culture. Lexington, MA: Lexington Books

Kosasi. (2016). Batombe pada Masyarakat Abai - Sangai: Studi Etnografi: Kesenian Di NagariAbai, Kecamatan Sangir, Kabupaten Solok Selatan. Diakses dari http://scholar. unand.ac.id/9939/2/BAB\%20I.pdf Pada 11 Juni 2017

Kusumawardani dan Faturochman. (2004). Nasionalisme. Diakses dari http:// download.portalgaruda.org/article.php?art icle $=369010 \& \mathrm{val}=7990 \&$ title $=$ Nasionalis me. Pada 27 Februari 2017

Lauer, J. (2008). Money as Mass Communication: U.S Paper Currency And The Iconography Of Nationalism. Diakses dari https:// mypages.unh.edu/sites/default/files/jlauer/ files/lauer_2008_money_as_mass_comm.f

\section{Pada 24 Mei 2017}

Lisbijanto, H. (2013). Batik. Yogyakarta: Graha Ilmu

Lubis, I. (2016). Makalah NKRI dalam Bingkai Kebhinekaan. Diakses dari https:// de.scribd.com/doc/294748775/makalahnkri Pada 28 Juni 2017

Mirnawati. (2012). Kumpulan Pahlawan Indonesia Terlengkap. Depok: Penebar Swadaya Grup

Napita, D. (2015). Makna Pictorial Health Warning Pada Kemasan Rokok dalam Mengomunikasikan Pesan Bahaya Merokok. Skripsi Universitas Padjadjaran.

Prihartiningrum, R. (2014). Perkembangan Tari Legong Keraton Gaya Peliatan Tahun 1928-1954. e-Journal Universitas Negeri Surabaya. Diakses dari jurnalmahasiswa. unesa.ac.id/article/10508/38/article.pdf pada 4 Mei 2017

Purwaningsih, E. (2005). Perkembangan Hukum Intellectual Property Rights: Kajian Hhukum terhadap Hak Atas Kekayaan Intelektual dan Kajian Komperatif Hukum Paten. Bogor: Ghalia Indonesia.

Qoimah, H. (2012). Karakteristik Batik Motif Sekar Jagad Yogyakarta. Diakses dari eprints.uny.ac.id/27606/1/Hafsah\%20 Qoimah\%2C\%2007207241004.pdf Pada 5 Mei 2017.

Rahayu, M.(2007).Pendidikan Kewarganegaraan: Perjuangan Menghidupi Jati Diri Bangsa. Jakarta: Grasindo

Sardiman, AM. (2011). Makna Lambang Garuda Pancasila Dan Pembentukan Karakter Bangsa. Diakses dari eprints.uny. ac.id/1028/1/Pancasila_dan_karakter.doc Pada 1 Mei 2017

Smith, A. (2003). Nasionalisme: Teori, Ideologi, dan Sejarah. Jakarta: Erlangga

Somantri, Lili. (2012). Potensi Pariwisata Nasional. e-Journal Universitas Pendidikan Indonesia Bandung. Diakses dari http://file.upi.edu/Direktori/FPIPS/ 
JUR._PEND._GEOGRAFI/132314541LILI_SOMANTRI/pariwisata.pdf Pada 21 Juni 2017

Syafei, M. (2013). Konstruksi Hubungan Pemerintah Pusat Dan Daerah Dalam Undang-Undang Nomor 11 Tahun 2006 Tentang Pemerintahan Aceh.Skripsi Universitas Lampung. Diakses dari digilib. unila.ac.id/5206/12/BAB\%20II.pdf Pada 12 Juni 2017

Vera, N.(2014). Semiotika dalam Riset Komunikasi. Bogor: Ghalia Indonesia

Victor, P. (2016). Analisis semiotika desain cover album "black market love" dari band superman is dead. Wacana, $X V(1), 66-85$

Wibowo, I. (2013). Semiotika Komunikasi: Aplikasi Praktis bagi Penelitian dan Skripsi Komunikasi. Mitra Wacana Media: Jakarta

Widayati, A. (2012). Fungsi Kesenian Ledhek Dalam Upacara Bersih Desa Di Dusun Karang Tengah, Desa Ngalang, Gedang Sari, Gunungkidul. Diakses dari eprints. uny.ac.id/9106/3/bab\%202-07209241008. pdf pada 24 Mei 2017

Yusran, W., Hafiar, H., \& Sjoraida, D. F. (2017). Analisis semiotik atas sampul Majalah Tempo Jakarta " Rizal Ramli petarung atau peraung ". Jurnal Informasi, 47(1). 